\title{
Structural constants of the internal logic of tennis
}

\section{Miquel Moreno}

Catalan Tennis Federation, Spain.

\begin{abstract}
This article discusses the factors that determine the structure of the sport of tennis based on the theories of motor action. It outlines a framework of tennis by reviewing the major theoretical contributions published and by identifying the most unique and specific elements of the game that every coach or athletic trainer needs to know when teaching the tennis concepts or planning and optimizing its training.
\end{abstract}

Key words: internal logic, motor action, tennis theory

Received: 20 February 2021

Acepted: 22 March 2021

Corresponding author: Miquel Moreno.Email: miquel.moreno@ fctennis.cat

\section{INTRODUCTION}

In the field of tennis teaching, coaches, physical trainers and other members of the multidisciplinary team should have a more or less broad epistemological knowledge of the factors that shape the structural uniqueness of the game of tennis.

In the present article we intend to approach the functional structure and the determinants of the game of tennis through the concept of internal logic, introduced in 1981 by Pierre Parlebas in its theoretical postulate on motor praxeology. This discipline, in the words of Lagardera $(1994$, p.23) tries to "explain the nature of the motor actions of games and sports, classify them, establish taxonomies and expose their internal logic". The internal logic, self Parlebas (1981, p.302) himself defined internal logic as: "the system of features that are relevant to a motor situation and the praxeal consequences that this system results in the game action ". We would say that the internal logic of tennis determines the phenomena, behaviours, and relationships that emerge from the very essence of the game and set up their motor action. The game action or motor action, can be defined as the perceptual processes, cognitive and lastly motoric that occur specifically in a sport enabling the cycle: perception (see the ball), decision (what to do with the ball) and execution (how I hit the ball).

\section{REVIEW}

The model proposed by Parlebas, has been very recognised and developed in the field of physical education by authors such as Lagardera $(1994 ; 2003)$ or Lavega (2003). Also, other noteworthy contributions are those of Hernandez-Moreno $(1994 ; 1995 ; 2000)$ in the area of sports initiation and it has been applied to a variety of sports such as futsal (HernandezMoreno, 2001), soccer (Marques, 2017), volleyball (Fotia, 2012), handball (Friedrich and Fagundes, 2020) or basketball (Sautu et al., 2009).

In the tennis context, Crespo (1990) presented a proposal of a functional structuring of the game, largely based on the model from Hernandez-Moreno (1987) which included in its categorisation the following parameters: space, time, rules, motor communication, motor strategy, technique and materials.

In our proposal we will focus on the structural constants classified by Parlebas (1981), and subsequently by Lagardera (1994): participants, space, time, implement and mobile. We consider the following elements: motor communication, motor strategy and technique mentioned by Crespo (1990) as inherent to the game action or the functional structure that may be addressed in later work (Figure 1).

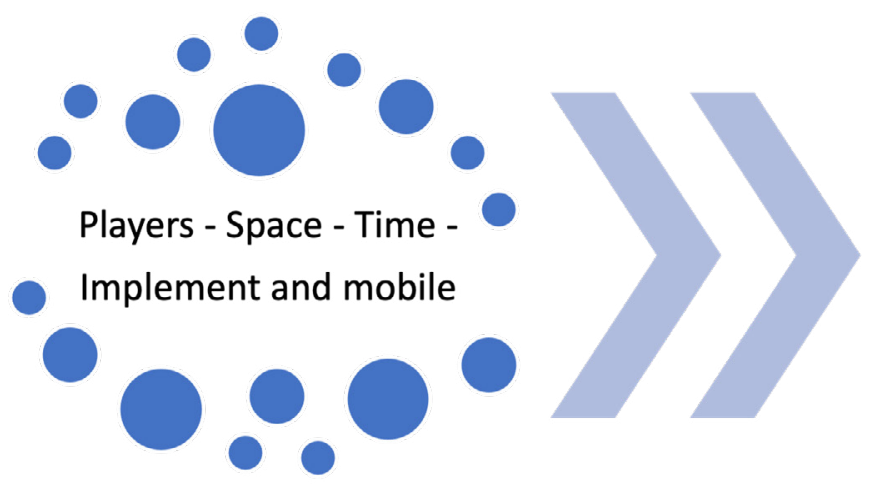

Structural constants

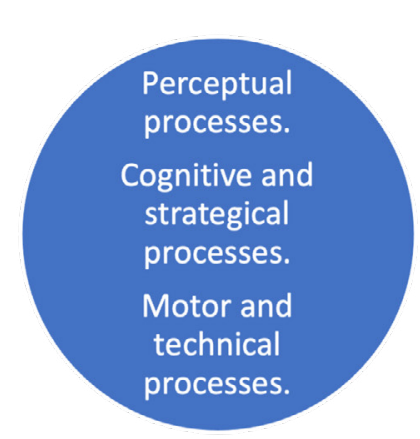

Game action

Figure 1. Structural constants and game action 


\section{DETERMINANT STRUCTURAL CONSTANTS IN TENNIS}

\section{The participants}

Tennis is a socio-motor sport, since it is developed through motor interactions between players. On the contrary, in psychomotor sports the participant does not interact with anyone during their practice (for example, swimming). Within the interactions between players, collaborative and oppositional interactions can be distinguished.

\section{Tennis as an opposition sport}

In the individual competition it occurs an opposition relationship between the actions and interests of the players. The successes of a player are opposed to the errors of the adversary. When a player wins, the opponent loses. When one player attacks, the opponent defends or counterattacks.

\section{Tennis as a collaborative sport}

In the doubles game, two players (partners) collaborate with each other to set up the opposition against the pair of opponents. This collaborative relationship is indirect and is produced from tactics, positions and strategies without the possibility or need for direct interaction.

In certain teaching-learning situations, it is convenient and common to use proposals for collaborative work between players in the form of patterns of play, exchanges and rallies.

\section{Tennis as an alternative interaction sport}

Tennis can be categorised within sports where the interaction occurs in an alternative way, in this case through the ball. One's hitting precedes the opponent's hit alternatively.

\section{The space of the game}

\section{Tennis as a game with stable spaces and subspaces}

Tennis takes place in a limited space. According to the Parlebas classification, the space in sports can be stable and standardised or unstable and a carrier of uncertainty. In the case of tennis, it is obvious that the space is stable and delimited, and the uncertainty can only appear due to weather aspects (wind) or be specific to the surface (irregular boats).

Another of the singularities of the space in the sport of tennis is its organization in subspaces, and its antithetical disposition (Crespo, 1999).

\section{Tennis and the adaptation of the space}

The space in tennis can be modified to favour the experience and the learning stages of development. Some studies such as Larsson and Guggenheimer (2013), Farrow and Reid (2020) or Buszard, Reid and Farrow (2017) provide evidence of how the proposed adaptation of spaces and materials of the ITF Play and Stay campaign (2007) has been favourable for tennis learning.

In tennis teaching and coaching, it is also common and recommended that coaches use different modifications of the sub-spaces to favour desired technical-tactical behaviours.

\section{Tennis as a long-distance confrontation duel}

Tennis would be part of long-distance duel sports, where the player's target is a certain space on the opponent's playing field. In other duel sports, the target would be in the body of the adversary as it happens in duel sports of zero (judo), reduced (boxing) or half (fencing) distance.

\section{The time}

We will adapt the time proposal by Menaut (1982) taking into consideration two differentiated time variables: internal synchrony and external diachrony.

\section{The external synchrony of tennis}

Tennis is a sport without time limit, the time is dependent on the score. The different scoring systems can modulate the match length. The playing surface is also an influencing factor on the total time of a match, on clay the length is greater than on a fast court and on grass are found the records of shorter duration (Fernández-García et al., 2012)

Equality between the players will be another component of temporal modulation, so that an even match where the points are distributed between both players in a very similar way will last longer than a match with greater inequality.

\section{The internal diachrony}

It refers to the sequential aspect of the game's own actions, at this point, we propose a two-dimensional differentiation:

\section{- Playing time}

It is the real time during which the game actions take place, that is, while the players are perceiving, deciding and executing and / or moving, hitting the ball and playing a point. This brings us to another of the structural singularities of tennis, the low percentage of playing time in relation to the total time of a match. According to a review of the characteristics of the temporal structure in tennis, Torres-Luque et al. (2014) established " the actual playing time is between $20 \%$ and $26 \%$ of the total game time".

\section{- Game rhythm}

The rhythm of the game refers to the time that elapses between shots, so that the less time between shots, the more rhythm of the game and more speed of the ball. It is an indicator related to the level of play of the players and the tactical dimension.

\section{Extracorporal objects}

The game action in tennis is carried out using two external, specific and singular materials: the racket (implement) and the ball (mobile). The characteristics of these objects are determined by the regulations.

\section{Tennis as an implement and mobile sport}

The mobile used in tennis is the ball. Through the ball, the strategic interaction and motor communication of the game takes place. The tactical behaviour of the player is expressed through the ball, in the form of directions, speeds, depths, heights, and spins.

The implement in tennis is the racket, it is used as an extension of the body itself to execute the main motor action of tennis, hitting. It interacts directly with the mobile, and leads to the technical motor expressions of tennis. 


\section{Tennis as an asymmetric sport}

The characteristics of the implement and the mobile in tennis configure another of its most important singularities, asymmetry. The fact of playing with a single implement and a single ball means that the players have to execute the majority of strokes with one arm and on one of the two sides of the body.

The preference of each player to use one or the other hand in the execution shows their manual laterality. In this area, Loffing (2012) has studied whether there is a certain advantage to develop in the sport of tennis being left-handed. His research shows that there is an increased presence of left-handers in the elite regarding the proportion in the normal population. To explain this significant difference, he proposes two theories that are still under discussion: the negative frequency of lefthanders, that is, playing against a left-hander is less common and this entails greater tactical difficulty; and on the other hand, the biological theory, which indicates that there could be certain innate conditions such as faster reaction speeds in the specialization of the right hemisphere, which controls contra-laterally the motor skills of the left arm.

\section{CONCLUSIONS}

The theoretical approach to the various elements reviewed in this article helps to understand the uniqueness of the game of tennis and its phenomena. The framework or map of the internal logic of the game of tennis presented can be useful to awaken the reflection of coaches and trainers, as an organizational proposal of contents in coach education courses or can be helpful as a basis for a further in-depth theoretical work.

\section{REFERENCES}

Buszard, T., Reid, M. y Farrow, D. (2017). Investigación inspirada en tennis Play and Stay. ¿Qué hemos aprendido sobre la modificación del material de tenis. ITF Coaching and Sport Science Review; 72 (25): 5 - 7

Crespo, M. (1999). Estructura funcional del tenis. Conferencia presentada al Congreso de la Asociación de Profesores de Tenis, Guatemala, CA.

Farrow, D., y Reid, M. (2010). Skill acquisition in tennis. In I. Renshaw, K. Davids, $\&$ G. J. P. Savelsbergh (Eds.), Motor Learning in Practice: A constraints-led approach (pp. 231-240). Routledge.

Fernández, J., Fernández-García, I., Mendez- Villanueva, A. (2005) Activity patterns, lactate profiles and ratings of perceived exertion (RPE) during a professional tennis singles tournament. En: M. Crespo. Quality coaching for the future. 14th ITF Worldwide coaches workshop. London, England: ITF.

Friedrich, E y Fagundes, M. F. (2020). Aproximações entre o Handebol e a Praxiologia Motriz: proposta de ensino com base nas problemáticas emergentes da Lógica Interna do jogo. Conexões: Esporte e Saúde, v. 18, p.120. https://doi.org/10.20396/conex.v18i0.8659163

Hernández-Moreno (1994). Fundamentos del deporte: análisis de la estructura de los juegos deportivos. Ed. Inde. Barcelona

Hernández-Moreno, J. (1995). La diversidad de prácticas. Análisis de la estructura de los deportes para su aplicación a la iniciación deportiva, en D. Blázquez (comp.): La iniciación deportiva y el deporte escolar, pp. 287-310. Barcelona: INDE.

Hernández-Moreno, J. (2000). La iniciación a los deportes desde su estructura y dinámica. Aplicación a la Educación Física Escolar y al Entrenamiento Deportivo. Barcelona: Inde.

Lagardera, F. (1994). La praxiología como nueva disciplina aplicada al estudio del deporte. Educación Física n 55 pp.21-30. La Coruña.

Lagardera, F. y Lavega, P. (2003). Introducción a la praxiología motriz. Barcelona: Paidotribo.

Larson, E. J., y Guggenheimer, J. D. (2013). The effects of scaling tennis equipment on the forehand groundstroke performance of children. Journal of sports science \& medicine, 12(2), 323-331.

Loffing, F., Hagemann, N., y Strauss, B. (2012). Left-handedness in professional and amateur tennis. PloS one, 7(11), e49325. https://doi.org/f4dkrv

Marques, C. (2017). O Goleiro de Futebol: uma visão a partir da Praxiologia Motriz. Brasileira de Futsal e Futebol, Edição Especial: Pedagogia do Esporte, São Paulo. v.9. n.35. p.406-415.

Menaut, A. (1982). Contribution a una approche theorique des jeux sportifs collectifs. Université de Bordeaux

Parlebas, P. (1981). Contribution a un lexique commenté en sciencie de l' action motrice. Paris. Insep.

Sautu, L. M., Garay, J. O., \& Hernández, A. (2009). Observación y análisis de las interacciones indirectas en el baloncesto ACB. Cuadernos De Psicología Del Deporte, 9, 69.

Torres-Luque, G., Sánchez-Pay, A., Fernández-García, Á.J., Palao, J.M. (2014). Características de la estructura temporal en tenis. Una revisión. Journal of Sport and Health Research. 6(2):117-128.

Attribution: You must give appropriate credit, provide a link to the license, and indicate if changes were made. You may do so in any reasonable manner, but not in any way that suggests the licensor endorses you or your use. 